\title{
A Cytogenetic Footprint for Mammary Carcinomas Induced by PhIP in Rats
}

\author{
A. T. Christian
}

This article was submitted to

$9^{\text {th }}$ International Congress of Toxicology, Brisbane, Australia, July 8-
12,2001

\section{April 1, 2001}

U.S. Department of Energy

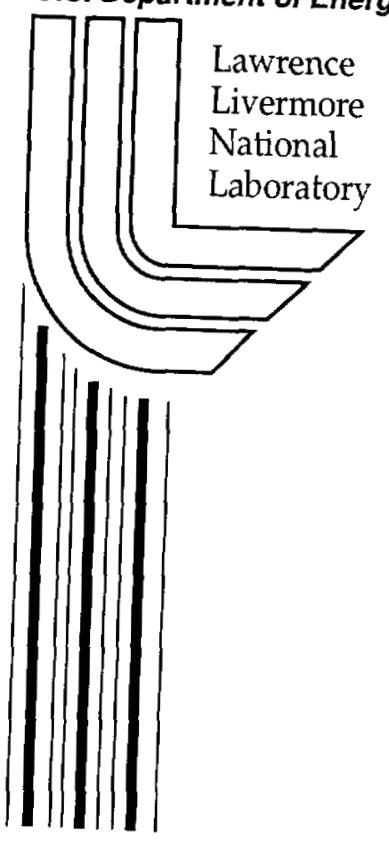




\section{DISCLAIMER}

This document was prepared as an account of work sponsored by an agency of the United States Government. Neither the United States Government nor the University of California nor any of their employees, makes any warranty, express or implied, or assumes any legal liability or responsibility for the accuracy, completeness, or usefulness of any information, apparatus, product, or process disclosed, or represents that its use would not infringe privately owned rights. Reference herein to any specific commercial product, process, or service by trade name, trademark, manufacturer, or otherwise, does not necessarily constitute or imply its endorsement, recommendation, or favoring by the United States Government or the University of California. The views and opinions of authors expressed herein do not necessarily state or reflect those of the United States Government or the University of California, and shall not be used for advertising or product endorsement purposes.

This is a preprint of a paper intended for publication in a journal or proceedings. Since changes may be made before publication, this preprint is made available with the understanding that it will not be cited or reproduced without the permission of the author.

This work was performed under the auspices of the United States Department of Energy by the University of California, Lawrence Livermore National Laboratory under contract No. W-7405-Eng-48.

This report has been reproduced directly from the best available copy.

Available electronically at http: $/ / w w w$. doc.gov/bridge

Available for a processing fee to U.S. Department of Energy And its contractors in paper from

U.S. Department of Energy

Office of Scientific and Technical Information P.O. Box 62

Oak Ridge, TN 37831-0062

Telephone: (865) 576-8401

Facsimile: (865) 576-5728

E-mail: reports@adonis.osti.gov

Available for the sale to the public from

U.S. Department of Commerce

National Technical Information Service

5285 Port Royal Road

Springfield, VA 22161

Telephone: (800) 553-6847

Facsimile: (703) 605-6900

E-mail: orders@ntis.fedworld.gov

Online ordering: http://www.ntis.gov/ordering.htm

OR

Lawrence Livermore National Laboratory

Technical Information Department's Digital Library

http://www.llnl.gov/tid/Library.html 
A Cytogenetic Footprint for Mammary Carcinomas Induced by PhIP in Rats.

\author{
Allen T. Christian \\ Biology and Biotechnology Research Program, Lawrence Livermore National Laboratory. P.O. Box 808, \\ L-452. Livermore, CA, 94551
}

\begin{abstract}
PhIP (2-amino-1-methyl-6-phenylimidazo [4,5-b] pyridine), a mutagen/carcinogen belonging to the class of heterocyclic amines (HCAs) found in cooked meats, is a mammary gland carcinogen in rats and has been implicated in the etiology of certain human cancers including breast cancer. To gain insight into the genomic alterations associated with PhIP-induced mammary gland carcinogenesis, we used comparative genomic hybridization $(\mathrm{CGH})$ to examine chromosomal abnormalities in rat mammary carcinomas induced by PhIP, and for comparison, by $\mathrm{DMBA}(7,12-$ dimethylbenz[a]anthracene), a potent experimental mammary carcinogen. There was a consistent and characteristic pattern of chromosome-region loss in PhIP-induced carcinomas that clearly distinguished them from carcinomas induced by DMBA.
\end{abstract}

This work was performed under the auspices of the U.S. Department of Energy by the Lawrence Livermore National Laboratory under contract No. W-7405-ENG-48 with support from NIH grant CA55861. 
$\mathrm{PhIP}$ belongs to the class of heterocyclic amine (HCA) food mutagens/carcinogens derived from cooked meats, and is the most prevalent of the known carcinogenic HCAs in the human diet. Mammary carcinogenesis in the carcinogen-treated rat and in the human is similar in the site of origin of carcinomas from ductal elements, the susceptibility of the mammary gland to initiation during mammary gland development (i.e., period of adolescence), and the hormonal responsiveness of the tumors; thus mammary carcinogenesis in rats is recognized as a valuable model for the human disease $[1,2]$. To determine the progression of PhIP-induced mammary carcinomas in rats, we have used a series of procedures to analyze the genomes of the cancerous cells, from gross chromosomal aberrations to single base mutations.

We examined by CGH carcinomas that were induced in female Sprague-Dawley rats by either PhIP or DMBA, a potent experimental mammary gland carcinogen belonging to the class of polycyclic aromatic hydrocarbons,. PhIP carcinomas were obtained from a previous study in which tumors were induced over a 25-week period after administration of $\mathrm{PhIP}(75 \mathrm{mg} / \mathrm{kg}$, p.o., once per day, for 10-days) or DMBA (10mg/kg, p.o., single dose) to 50-day old rats [3]. Vehicle control animals were run in parallel in both the PhIP and DMBA studies, and none of the control rats developed mammary carcinomas [4]. This technique produces cancers only in animals treated with the specific agent, avoiding spontaneous tumors that can complicate analyses $[5,6]$.

Although routinely applied to studies of the genomic alterations in mouse and human tumors, CGH has not been widely utilized in studies of the rat genome. It is used to detect genomic changes such as losses, gains and amplifications of chromosomes and chromosome regions, and can provide valuable information about solid tumors from which metaphase cells are difficult to obtain [7-9]. We examined 9 different tubulopapillary carcinomas, 6 induced by PhIP and 3 induced by DMBA. All 9 carcinomas contained genomic changes detectable by CGH as either losses or gains/amplifications of chromosomal regions. We found a consistent and characteristic pattern of chromosome-region loss in PhIP-induced carcinomas that clearly distinguished them from carcinomas induced by DMBA.

With the long-term goal of determining which genes in these common deleted regions are involved in PhIP-induced mammary carcinogenesis, we developed a method, referred to as gene recovery microdissection (GRM), to generate chromosome region-specific cDNA libraries to characterize and map the expressed genes in normal rat mammary gland. This approach is generally applicable for studies of species with incompletely characterized genomes, such as the rat, and will enable us to characterize the PhIP signature at the genetic level.

While the rat is a valuable experimental model for studies of carcinogenesis, rat genetics remains relatively understudied compared with mouse and human. Since the rat genome has not yet been mapped to the extent of humans or even mice, it is currently difficult to determine which genes in these deleted regions might be important for tumorigenesis. Thus, another means must be used to identify the known or novel genes in these regions that are expressed in normal rat mammary tissue and might therefore be important in carcinogenesis. We have developed a technique that combines HeadStart microdissection [10] with a process variously referred to as preparative in situ hybridization [11] or microdissection-mediated cDNA capture [12, 13]. GRM is a means for creating a chromosome region-specific cDNA library for any species and tissue from a single microdissected normal metaphase chromosome, eliminating the need to dissect multiple copies of the target. The process involves hybridizing a cDNA library specific for the species and tissue of interest onto degenerate oligonucleotide primed-PCR amplified metaphase chromosomes. This step also normalizes the library, increasing the ratio of less prevalent to more prevalent expressed genes [14]. PCR is used again to amplify the cDNA molecules in situ 
following hybridization, and the desired chromosome regions are isolated by microdissection. The cDNA molecules hybridized to the dissected genomic DNA are then amplified by PCR in a tube by using primers specific for the linker arms on the cDNA. The cDNA molecules are then cloned and sequenced. In situ amplification followed by microdissection allows complex libraries to be made from single microdissected chromosomes and chromosome regions, possibly by increasing both the number of targets for in situ hybridization and probe accessibility to the target chromosomes. Once likely target genes have been selected, cDNA libraries from tumors can be made and the mRNA representing the expressed gene can be isolated and sequenced. This allows variation in the genetic sequence to be found. The GRM technique provides a valuable link between the cytogenetic and physical mapping techniques that will quickly and reliably determine which genes are expressed in specific chromosomal regions of a particular tissue.

Once mutations in a particular gene have been discovered, it is desirable to learn where in the tumor these changes occur, as the location of a particular mutation can give some indication of its role in tumor initiation and progression. To locate these point mutations, we have modified the procedure called rolling circle amplification (RCA) to function in fixed cells and tissue sections. The utility of RCA has been well documented [15-19]. RCA is a molecular cytogenetic technique used in conjunction with a 'padlock' oligonucleotide probe to locate and detect single base changes in DNA and RNA. Padlock probes are sequences comprised of $\sim 100$ nucleotides designed to hybridize to targets of approximately 30 bases, of which 15 are present in opposite orientation at each end such that the hybridized probe forms a circle with adjacent $3^{\prime}$ and $5^{\prime}$ termini $[20,21]$. At 10 bases per helical turn, the hybridized probe is wrapped around its target 3 times, with the remaining 70 bases forming an unhybridized single-stranded loop. Posthybridization DNA ligation is used to connect the two ends of the probe in the middle of the 30 base binding region. The 70 base loop that is not bound to the target not only facilitates circularization of the probe, but permits approximately 20 bases to serve as a primer recognition site enabling DNA polymerase to replicate the circle. RCA is an isothermal process in which the polymerase progresses continuously around the loop until the 100 bases have been replicated hundreds or thousands of times. Incorporating a labeled nucleotide during the RCA reaction produces sufficient signal to permit easy visualization of the target. To detect point mutations, the padlock probe is designed to place one of the two terminal bases directly over a predetermined base of the target. To ascertain whether a particular base is mutated, two or more nearly identical vectors are constructed, one containing the complement to the normal base and the others complementary to the mutated base. If the terminal base in the probe is not complementary to the target, that base will not hybridize, preventing ligation and blocking the polymerase from progressing continuously around the loop with the result that no fluorescent signal will be generated. Consequently, the mutant and normal target sequences will only be detected by their respective probes. Designing a series of vectors to produce signals in different colors following the RCA allows, in effect, single nucleotide polymorphisms to be detected rapidly and efficiently.

When used in succession, CGH, GRM and RCA enable carcinomas to be analyzed from the gross cytogenetic level to the single base mutation. In this way, the genetic progression of the tumor can be studied. 


\section{References}

1. Russo, J., B.A. Gusterson, A.E. Rogers, I.H. Russo, S.R. Wellings, and M.J. van Zwieten, Comparative study of human and rat mammary tumorigenesis. Lab Invest, 62(3): p. 244-78 1990.

2. Russo, J., I.H. Russo, A.E. Rogers, M.J. van Zwieten, and B. Gusterson, Pathology of tumours in laboratory animals. Tumours of the rat. Tumours of the mammary gland. IARC Sci Publ, 99: p. 47-78 1990.

3. Ghoshal, A., K.H. Preisegger, S. Takayama, S.S. Thorgeirsson, and E.G. Snyderwine, Induction of mammary tumors in female Sprague-Dawley rats by the food- derived carcinogen 2-amino-1-methyl-6-phenylimidazo[4,5-b]pyridine and effect of dietary fat. Carcinogenesis, 15(11): p. 2429-33 1994.

4. Snyderwine, E.G., U.P. Thorgeirsson, M. Venugopal, and S.J. Roberts-Thomson, Mammary gland carcinogenicity of 2-amino-1-methyl-6-phenylimidazo[4,5-b]pyridine in Sprague-Dawley rats on high- and low-fat diets. Nutr Cancer, 31(3): p. 160-7 1998.

5. Huggins, C., Briziarelli, G., Sutton Jr., H., Rapid induction of mammary carcinoma in the rat and influence of hormones on the tumors. J. Exp. Med., 109: p. 25-49 1959.

6. Huggins, C., Grand, L.C., Billantes, F.P., Mammary cancer induced by a single feeding of nuclear hydrocarbons, and its suppression. Nature, 189: p. 204-207 1961.

7. Kallioniemi, A., O.P. Kallioniemi, D. Sudar, D. Rutovitz, J.W. Gray, F. Waldman, and D. Pinkel, Comparative genomic hybridization for molecular cytogenetic analysis of solid tumors. Science, 258(5083): p. 818-21 1992.

8. Kallioniemi, A., O.P. Kallioniemi, F.M. Waldman, L.C. Chen, L.C. Yu, Y.K. Fung, H.S. Smith, et al., Detection of retinoblastoma gene copy number in metaphase chromosomes and interphase nuclei by fluorescence in situ hybridization. Cytogenet Cell Genet, 60(3-4): p. 190-3 1992.

9. Gray, J.W. and D. Pinkel, Molecular cytogenetics in human cancer diagnosis. Cancer, 69(6 Suppl): p. 1536-42 1992.

10. Christian, A.T., H.E. Garcia, and J.D. Tucker, PCR in situ followed by microdissection allows whole chromosome painting probes to be made from single microdissected chromosomes. Mamm Genome, 10(6): p. 628-31 1999.

11. Hozier, J., R. Graham, T. Westfall, P. Siebert, and L. Davis, Preparative in situ hybridization: selection of chromosome region- specific libraries on mitotic chromosomes.

Genomics, 19(3): p. 441-7 1994.

12. Gracia, E., U. Fischer, A. elKahloun, J.M. Trent, E. Meese, and P.S. Meltzer, Isolation of genes amplified in human cancers by microdissection mediated cDNA capture. Hum Mol Genet, 5(5): p. 595-600 1996.

13. Gracia, E., M.E. Ray, M.H. Polymeropoulos, A. Dehejia, P.S. Meltzer, and J.M. Trent, Isolation of chromosome-specific ESTs by microdissection-mediated cDNA capture. Genome Res, 7(2): p. 100-7 1997.

14. Bonaldo, M.F., G. Lennon, and M.B. Soares, Normalization and subtraction: two approaches to facilitate gene discovery. Genome Res, 6(9): p. 791-806 1996.

15. Lizardi, P.M. and D.C. Ward, FISH with a twist. Nat Genet, 16(3): p. 217-8 1997.

16. Thomas, D.C., G.A. Nardone, and S.K. Randall, Amplification of padlock probes for DNA diagnostics by cascade rolling circle amplification or the polymerase chain reaction. Arch Pathol Lab Med, 123(12): p. 1170-6 1999. 
17. Schweitzer, B., S. Wiltshire, J. Lambert, S. O'Malley, K. Kukanskis, Z. Zhu, S.F. Kingsmore, et al., Inaugural article: immunoassays with rolling circle DNA amplification: A versatile platform for ultrasensitive antigen detection [In Process Citation]. Proc Natl Acad Sci US A, 97(18): p. 10113-9 2000.

18. Baner, J., M. Nilsson, M. Mendel-Hartvig, and U. Landegren, Signal amplification of padlock probes by rolling circle replication. Nucleic Acids Res, 26(22): p. 5073-8 1998.

19. Lizardi, P.M., X. Huang, Z. Zhu, P. Bray-Ward, D.C. Thomas, and D.C. Ward, Mutation detection and single-molecule counting using isothermal rolling-circle amplification. Nat Genet, 19(3): p. 225-32 1998.

20. Nilsson, M., H. Malmgren, M. Samiotaki, M. Kwiatkowski, B.P. Chowdhary, and U. Landegren, Padlock probes: circularizing oligonucleotides for localized DNA detection. Science, 265(5181): p. 2085-8 1994.

21. Nilsson, M., K. Krejci, J. Koch, M. Kwiatkowski, P. Gustavsson, and U. Landegren, Padlock probes reveal single-nucleotide differences, parent of origin and in situ distribution of centromeric sequences in human chromosomes 13 and 21 [see comments]. Nat Genet, 16(3): p. 252-5 1997. 